\title{
A Model for Disentangling Dependencies and Impacts among Human Activities and Marine Ecosystem Services
}

\author{
Andreas Bryhn $\mathbb{1}^{1} \cdot$ Patrik Kraufvelin ${ }^{1} \cdot$ Ulf Bergström ${ }^{1} \cdot$ Max Vretborn ${ }^{2} \cdot$ Lena Bergström $^{1}$
}

Received: 25 September 2019 / Accepted: 31 January 2020 / Published online: 27 February 2020

(c) The Author(s) 2020

\begin{abstract}
Understanding and communicating the links among human activities and marine ecosystem services are fundamental for ecosystem-based management, which aims at attaining ecological, economic and social sustainability in the use of our seas. Relationships are typically complex and may differ between geographic areas. Here, an assessment model that combines available quantitative, semi-quantitative and qualitative information, rooted in the DAPSIR (Driver-Activity-PressureState-Impact—Response) framework and assessment requirements of the EU Marine Strategy Framework Directive, is developed and applied. Focusing on Swedish marine waters, major human activities at sea are evaluated in relation to their dependencies and impacts on the status of marine ecosystem services. This case study is a consensus assessment based on evaluation of available literature and data. By relating degrees of dependencies and impacts to values of different economic sectors, discrepancies among sectors with respect to their impact versus their monetary value can be identified. In our case, commercial fishing depends on and influences a wide range of ecosystem services, while other sectors, such as shipping, depend little on marine ecosystem services. At the extreme end of the range, pressures from human activities in the past, such as historical nutrient emissions, still have prominent influence on ecosystem services today, entailing considerable losses. Marine tourism and commercial fishing show similar dependencies on ecosystem services, but tourism has a clearly lower impact on ecosystem services and a higher monetary value. The model may serve as a useful tool for communicating and guiding priorities in integrated environmental management and maritime spatial planning.
\end{abstract}

Keywords Assessment model $\cdot$ Ecosystem services $\cdot$ DAPSIR $\cdot$ Ecosystem-based management $\cdot$ Marine fisheries $\cdot$ Marine tourism

\section{Introduction}

Human use of marine waters and resources has strongly altered the structure and function of many marine ecosystems worldwide (Halpern et al. 2008, 2015; Rocha et al. 2015; Selim et al. 2016; Österblom et al. 2017). Impacts

Supplementary information The online version of this article (https:// doi.org/10.1007/s00267-020-01260-1) contains supplementary material, which is available to authorized users.

Andreas Bryhn

andreas.bryhn@slu.se

1 Swedish University of Agricultural Sciences, Department of Aquatic Resources, Institute of Coastal Research, Skolgatan 6, 74242 Öregrund, Sweden

2 Swedish Agency of Water and Marine Management, Gullbergs Strandgata 15, 41104 Göteborg, Sweden have been manifested as various adverse environmental effects, such as fish stock declines or collapses (Worm 2016), loss of biodiversity (Mazor et al. 2018), eutrophication (Schernewski et al. 2015), harmful levels of toxic pollutants (Carlsson et al. 2016), littering (Bergmann et al. 2015) and depletion of valuable habitats (Airoldi and Beck 2007). Thus, human activities also cause effects on marine ecosystem services; i.e., the benefits that people and societies receive from marine ecosystems, and which concurrently serve as preconditions for many human activities related to the sea (World Resources Institute 2005; Barbier 2017). The connection between the state of human activities and ecosystem services (Costanza et al. 2014; Boumans et al. 2015; Anderson et al. 2016) is especially evident in coastal areas, which contain some of the highest valued ecosystem services globally (Costanza et al. 1997, 2014; de Groot et al. 2012; Culhane et al. 2018), while often facing extensive pressure from human activities (Lotze et al. 2006; Elliott et al. 2018). 
Importantly, ecosystem services are produced in the dynamic and multi-faceted interface between social and ecological systems (Bennett et al. 2015). Ecosystem components, such as species and habitats, are the basis of ecosystem functions (Palumbi et al. 2009; Ceballos et al. 2015; Hautier et al. 2015), which maintain ecosystem services and may also induce positive impacts on human well-being (Sandifer et al. 2015). Hence, explicit consideration of ecosystem services in environmental management and spatial planning can be expected to lead to improved longterm societal and environmental outcomes (Arkema et al. 2015). In this context, it is imperative for management to consider in which ways species and habitats, the functions they provide, and hence the flow of ecosystem services, can be affected by various human activities (Giakoumi et al. 2015; Mach et al. 2015). As ecosystem services are associated with high societal values (monetary or non-monetary), the consideration of these linkages may, further, support the bridging of different management perspectives, and eliminate or dampen conflicts between development and environmental protection (Balmford et al. 2002; de Groot et al. 2010).

Analyses of ecosystem services are increasingly included in environmental management, although hitherto at a much more limited extent for marine systems than for terrestrial environments (Liquete et al. 2013; Inácio et al. 2018; Schernewski et al. 2018). Among the marine examples, the global Millennium Ecosystem Assessment (World Resources Institute 2005) identified fishing as the most prominent driver of changes in ecosystem services, while Rocha et al. (2015) highlighted excessive anthropogenic nutrient load leading to eutrophication and hypoxia as a major determinant of marine ecosystem functioning and services. Martin et al. (2018) made a qualitative investigation of connections between human activities and ecosystem services in relation to coastal nutrient management in Massachusetts, USA, and found rather diverse effects on ecosystem services depending on which human activity was studied. In the Baltic Sea, Inácio et al. (2018) developed an assessment tool for marine ecosystem services and applied it to conditions in two coastal lagoons with results differing strongly between the lagoons. Furthermore, there may be a considerable spatial mismatch between human impacts, ecosystem functioning, and marine ecosystem services (Lindegren et al. 2018), and non-linear responses are common (Hunsicker et al. 2015). Thus, while analyses of how impacts of human activities affect ecosystem services globally are vital (Costanza et al. 2014; Lindegren et al. 2018), they will inevitably be connected to considerable data and assessment challenges and a high level of sitespecificity and context-dependency (Kok et al. 2017).

For policy-makers, managers and stakeholders, it may be challenging to understand and communicate ecosystem

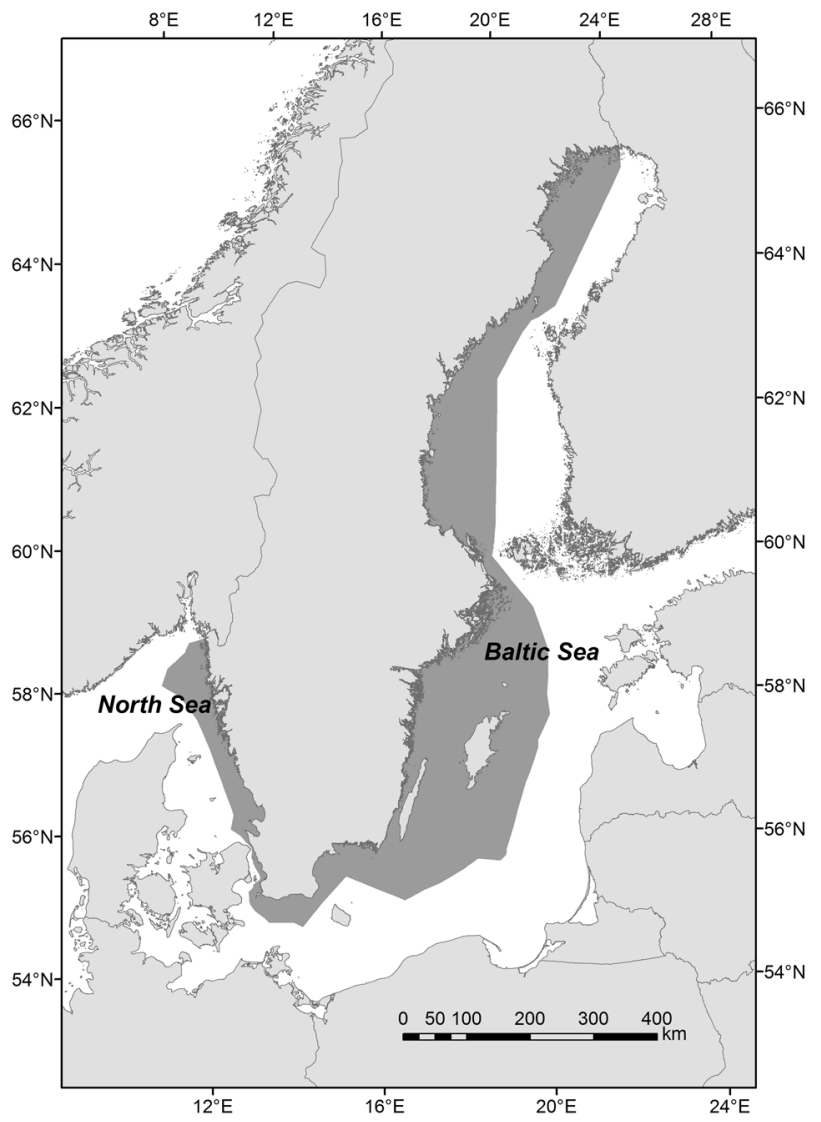

Fig. 1 The Swedish marine economic zone (dark grey colour) in Northern Europe, covering a substantial part of the Baltic Sea as well as the easternmost part of the North Sea

services and associated analyses from an integrated perspective (Beaumont et al. 2007). To address these challenges, this study presents an assessment model for exploring, comparing and communicating dependencies and impacts of human activities on marine ecosystem services over multiple sectors at an overarching policy level. The assessment model addresses three major questions: (1) to what extent are marine ecosystem services affected by different human activities, (2) to what extent are different human activities dependent on specific marine ecosystem services and (3) how do these relationships compare with the economic performance of different sectors of sea use. The assessment model is applied in an example from Swedish coastal and marine waters located in Northern Europe, covering parts of the western and northern Baltic Sea and the eastern North Sea (Fig. 1; see motivation for selecting the study area in the following section). The assessment model connects to recurrent policy practice in relation to the EU Marine Strategy Framework Directive, where addressing the state of the environment in relation to our use of marine waters and impacts on ecosystem services and human well-being is a key element (EC 2008, 2017; Elliott et al. 2017), but it is also of relevance for other 
situations when there is a need to address multidimensional interlinkages between economic and environmental aspects.

\section{Materials and Methods}

The study area encompasses Swedish coastal and marine waters (Fig. 1), which represent a rather diverse mix of urban and industrial areas, popular recreational areas, sparsely populated regions, as well as open marine waters with marine shipping routes and various levels of fishing pressure. The approach used in this study is exemplified at this overarching scale, as governmental bodies responsible for marine environmental management often have geographically wide (national) mandates (Schreiber and Linke 2018; Haight et al. 2019), and there is therefore a need for analyses and syntheses of information across sectors at this scale.

Our assessment model aligns with the generic DriverActivity-Pressure-State change-Impact-Response (DAPSIR) framework (Fig. 2), which is widely used in environmental management as a way to describe causal relationships between society and the environment (Atkins et al. 2011; Patrício et al. 2016; Martin et al. 2018). The DAPSIR framework is useful to support the shared understanding among actors, including representatives of science, policy-makers, managers and stakeholders, and has subsequently been developed into various adaptations (Patricio et al. 2016; Elliott et al. 2017). The basic framework outlines the causal links between drivers, activities, pressures, environmental status, impacts, and responses in a management setting (Atkins et al. 2011). Figure 2 illustrates the

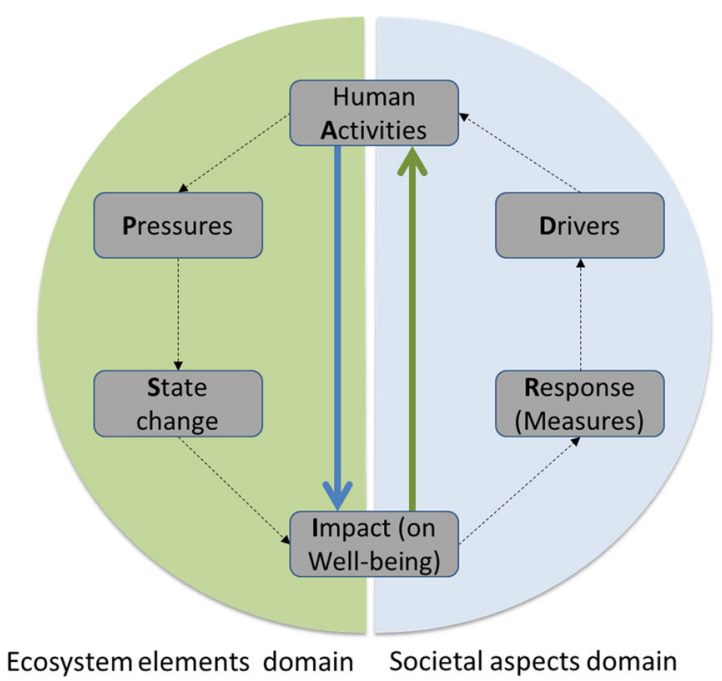

Fig. 2 Illustration of how the DAPSIR framework is applied in this work, focusing on the reciprocal relationships between human activities and impacts (ecosystem services), as highlighted by the thick vertical arrows focal aspects for the purposes of this work: the human activities (A), which may cause pressures on the environment and subsequent effects on ecosystems, as illustrated in the left-hand side of the cycle, and the impacts (I) on ecosystem services and human well-being, which may occur as a result. The results are relevant for the development of management responses, by providing information on which measures may be required, and potentially for guiding policies aimed at changing the drivers of human activities. Hence, analyses based on the DAPSIR framework not only provide information about how different activities may influence the marine environment, including the provisioning of ecosystem services, but also about how human activities depend on the environment and the likely associated incentives to change from status quo.

The first two steps in the evaluation correspond to assessing the likely influence of human activities on the status of ecosystem services, and vice versa, as illustrated by the vertical thick arrows in Fig. 2. Thus, the complete causal impact chain (human activities-pressure-stateimpact) is not central, although this can be included by embedding more detailed information from cascade models when available (Haines-Young and Potschin 2010; La Notte et al. 2017). For the purposes of this study, the estimations were performed as an internal consensus expert evaluation with structured elicitation supported by a literature review (see McBride et al. 2012; Smith et al. 2015; more information below).

The matrix for evaluation encompassed a wide range of human activities and marine ecosystem services (Tables 1 and 2). In all, 21 human activities were assessed, representing ongoing activities in Swedish seas today and using terminology and classification aligned with Annex III in EC (2017) (Table 1). In addition, five still enduring ambient pressures that are not directly connected to ongoing human activities were included. Most prominently, sedimentary internal loading of nutrients and contaminants emanating from past anthropogenic emissions still give rise to pressures in the marine environment in the assessed area (HELCOM 2018). Furthermore, environmental pressures related to climate change were included without being linked to certain ongoing human activities. For this, a decrease in surface water salinity, an increase in water temperature and an increase in carbon dioxide that may cause acidification are used; see BACC II author team (2015). Several human activities in the study area are likely to exacerbate global climate change, but a vast majority of the impact is due to past and globally occurring activities (Schuur et al. 2015).

With regard to ecosystem services, a multitude of classifications and typologies exist (e.g. Böhnke-Henrichs et al. 2013; Hasler et al. 2016; Ivarsson et al. 2017; Maes et al. 2018). The diversity partly reflects that this is a field in 
Table 1 Human activities considered in the study, as well as pressures from past activities

Activity

Land claim

Restructuring of seabed morphology, including dredging and depositing of materials

Extraction of minerals (rock, metal ores, gravel, sand, shell)

Renewable energy generation (wind, wave and tidal power), including infrastructure

Nuclear power (uptake and discharge of cooling water)

Transmission of electricity and communications (cables)

Fish and shellfish harvesting (professional)

Hunting and collecting for other purposes

Aquaculture - marine, including infrastructure

Agriculture

Forestry

Transport — infrastructure

Transport — shipping

Urban uses

Industrial uses

Waste treatment and disposal

Tourism and leisure infrastructure (including marinas)

Tourism and leisure activities (including boating)

Fish and shellfish harvesting (recreational)

Security/defense (military)

Research, survey and educational activities

Pressures from past activities

Eutrophication legacy

Contamination legacy

Climate change carbon dioxide $\left(\mathrm{CO}_{2}\right)$

Climate change temperature

Climate change salinity

development, but partly also the need for adapting functionally operative systems for different purposes. However, many of the existing typologies are still comparable at some level of classification. For the purposes of this work, a Swedish national marine typology developed by Garpe (2008), and further elaborated by Bryhn et al. (2015) was used. This typology includes 23 ecosystem services distributed over three groups: regulating and supporting, provisioning as well as cultural ecosystem services (Table 2).

In the present evaluation, the first two steps were performed by authors $\mathrm{AB}, \mathrm{PK}, \mathrm{UB}$ and $\mathrm{LB}$, who were tasked to synthesize the current level of knowledge in the field for the concerned geographical area. The four academic experts were selected by the Swedish Agency of Marine and Water Management (SwAM). The newest available assessment sources were identified as SwAM (2012, 2018a-d), Bryhn et al. (2015), OSPAR (2017), and HELCOM (2018), which were supplemented with results from research papers.
Table 2 Marine ecosystem services in the Swedish marine economic zone (remade from Bryhn et al. 2015)

\begin{tabular}{ll}
\hline Regulating and supporting & Provisioning \\
\hline RS1: Biogeochemical cycling & P1: Food \\
RS2: Primary production & P2: Raw material \\
RS3: Food web dynamics & P3: Genetic resources \\
RS4: Biodiversity & P4: Chemical resources \\
RS5: Habitat & P5: Ornamental resources \\
RS6: Resilience & P6: Energy \\
RS7: Climate and atmospheric & \\
regulation & \\
RS8: Sediment retention & Cultural \\
RS9: Regulation of eutrophication & C1: Recreation \\
RS10: Biological regulation & C2: Aesthetic values \\
RS11: Regulation of toxic substances & C3: Science and education \\
& C4: Cultural heritage \\
& C5: Inspiration \\
& C6: Natural heritage \\
\hline
\end{tabular}

The letters preceding each ecosystem service indicate their categorization into either regulating and supporting (RS), provisioning $(\mathrm{P})$, or cultural $(\mathrm{C})$ ecosystem services

Referring to areas of expertise, the group represented research, environmental monitoring and assessment on ecosystem-based management and ecosystem services $(A B$, LB), impacts of human activities including in particular fishing (UB, AB), toxic pollutants $(\mathrm{AB})$ eutrophication (AB, $\mathrm{PK})$, non-indigeneous species $(\mathrm{PK})$, habitat deterioration (PK, UB) and marine renewable energy (LB) as well as marine ecology and food webs including ecosystem functioning, green infrastructure and restoration (PK, UB, LB).

\section{Step 1. Impacts of Human Activities on Marine Ecosystem Services}

Impacts from each of the human activities on each of the ecosystem services were estimated applying an ordinal classification scale of $0-4$, where 4 represents the highest impact and 0 no impact, focusing on negative impacts. Potentially positive impacts (e.g., added hard surfaces in connection with shipwrecks, coastal construction or when deploying artificial reefs) were regarded as very minor at the large scale considered in this study and were therefore not assessed.

The scores were assigned in a matrix covering all combinations of the assessed human activities and ecosystem services (Supplement 1), considering information on the intensity of pressure caused by each activity as well as its geographical prevalence in the assessed area. Impacts from a human activity causing an intense pressure but with a relatively limited spatial extent attained a lower score than a less intense pressure acting over a wider area. For instance, 
marine aquaculture may cause relatively strong pressures in the form of physical habitat loss or nutrient inputs, but has a restricted geographical extent in Sweden (Statistics Sweden 2017). Conversely, shipping may be attributed to pressures of relatively low intensity (underwater noise, wakes, nutrient input, littering, or potential spread of non-indigenous species) but is much more widespread (Klusek 2016).

In a first step, author PK provided individual scores to all combinations of human activities and ecosystem services based on the above indicated sources. Following this initial scoring, all assessors (AB, PK, UB, LB) gathered, scrutinized the matrix, and wherever differing views appeared, reevaluated available evidence in order to reach consensus. When doing so, the results were scrutinized from both of two perspectives: assessing each human activity in relation to all ecosystem services, as well as each ecosystem service in relation to all human activities. The purpose of this procedure was to screen for potential inconsistencies in the scaling of scores for different human activity and ecosystem service combinations, and scores were adjusted when motivated.

\section{Step 2. Dependencies of Human Activities on Ecosystem Services}

For estimating the dependencies of each of the human activities on each of the ecosystem services (Tables 1, 2), assessment steps recommended by Ivarsson et al. (2017) were considered. The resulting scores were compiled in a second matrix (Supplement 2). The evaluation built on previous work by SWaM (2012), within which a lower number of human activities were evaluated using binary $(0$ and 1) scoring. However, in the current study, five ordinal classes (0-4) were applied, where the highest score (4) corresponds to the highest dependency. The evaluation process followed the same procedure as in the assessments of impacts on ecosystem services (Step 1): Initial scores provided by author PK based on agreed criteria, followed by group discussion, evaluation of results, and scrutinization in relation to other combinations of human activities and ecosystem services, to reach a consensus score. In this assessment, pressures from past activities (Table 1) were assigned values zero, as being independent of current marine ecosystem services.

Hence, reflecting the aim to reach a generic consensus assessment, only integers were reported in the results. Uncertainty was not assessed since the focus of the study was on developing the model for assessing dependencies and impacts among human pressures and ecosystem services. Adding an uncertainty estimation of the scores is a clear topic for later refinement of the method but will require a separate consideration given the broad and overarching assessment scale.
In a final step, the scores within each of the two matrices were summed up for both human activities and ecosystem services (rows and columns in each matrix) to attain an overall measure of their cumulative impact/dependency on each other (Supplements 1, 2). In the aggregated scores, all ecosystem services categories and all activity categories were given equal importance weighting. The process to develop consensus scores in the two assessments required five dedicated meetings plus shorter follow-ups by short meetings or e-mail.

\section{Step 3. Combining the Evaluation Outcomes}

In a third step, information on monetary value was collected for all activities for which such data were available. The monetary value estimates comprised the value added by specific marine sectors, based on national statistics using the Statistical Classification of Economic Activities in the European Community (NACE) codes for each activity according to Statistics Sweden (SwAM 2017), with the addition of unpublished data on recreational fishing from SwAM. In our applied example, this part of the analysis included some aggregated activity categories compared with those applied in steps 1 and 2, depending on the available aggregations for data on economic values. Here, we had economic data for marine tourism, and importance scores for marine tourism were obtained by taking the maximum values of the activities categories 'tourism and leisure infrastructure' and 'tourism and leisure activities'. This was regarded among the assessors as a suitable precautionary method.

To indicate the relative dependency and potential negative impact on marine ecosystem services of the different human activities, the tallied total scores from the evaluations attained in steps 1 and 2 were used. The assessment results were combined by plotting the sum of scores for the dependency of each human activity on ecosystem services versus the sum of scores for their impacts on the same, to reflect the extent of interdependencies between human activities and ecosystem services.

\section{Results}

The applied results for the Swedish coastal and marine area are presented in Figs 3-6 and in the Supplement. The expert assessment shows the relative extent to which various human activities potentially impact on the status of ecosystem services and are dependent on these in Swedish coastal and marine areas. According to this evaluation, commercial and recreational fish and shellfish harvesting, agriculture and waste treatment and disposal, out of the examined activities, had the highest ratings regarding 
Fig. 3 Rank order of marine ecosystem services in relation to how much they are impacted by human activities, according to the applied expert judgement
Fig. 4 Rank order of marine ecosystem services in relation to their summed importance for human activities, according to the applied expert judgement
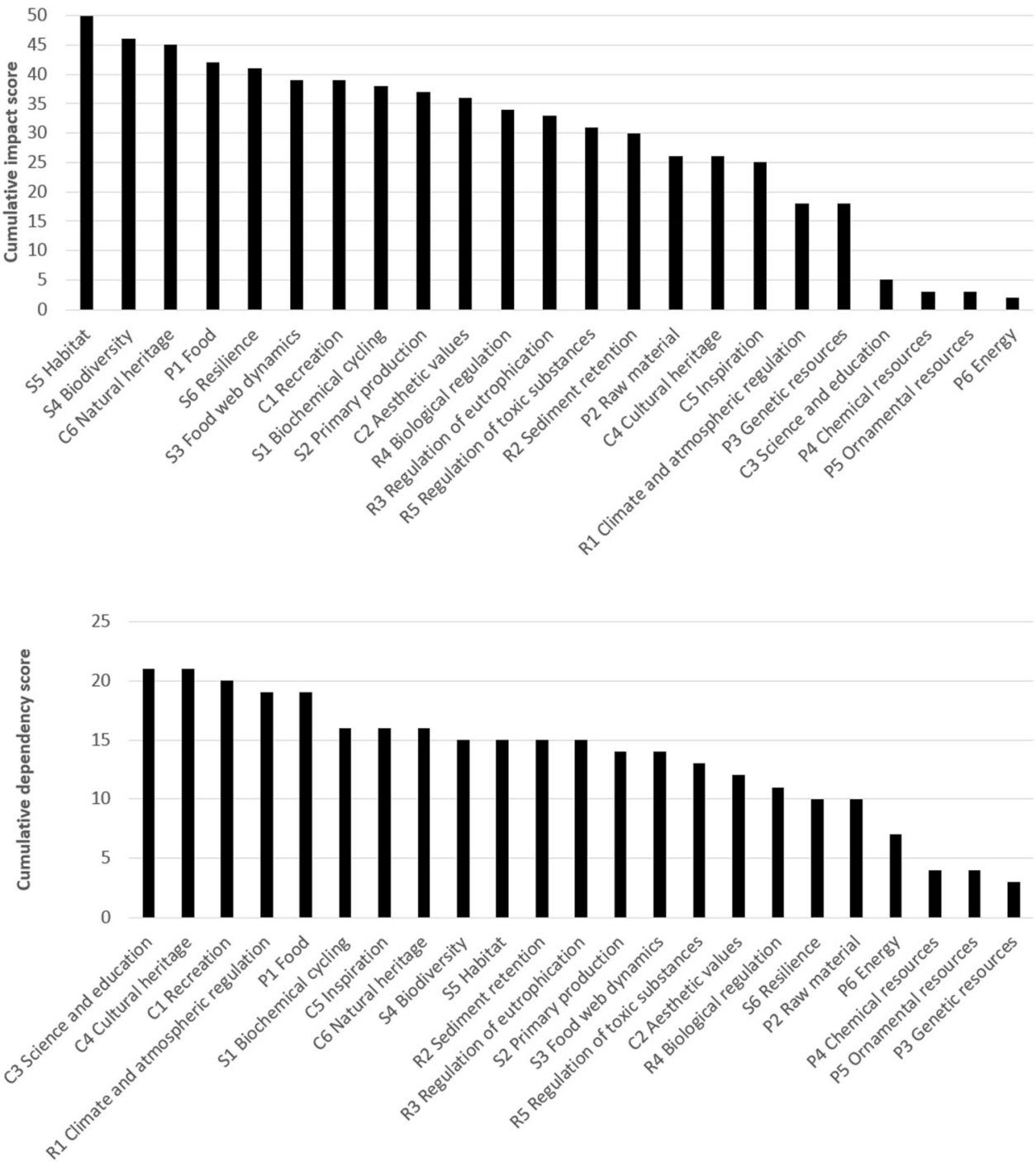

influence on ecosystem services. However, the background pressures eutrophication due to past activities, and climate change related temperature increase and salinity decrease were also identified as important (Supplement 1). Other activities had a relatively smaller impact on ecosystem services in this assessment. The most strongly impacted ecosystem services were identified among the regulating and supporting services, 'Habitat' and 'Biodiversity', but for instance the provisional service 'Food' and the cultural service 'Recreation' were also relatively highly rated (Fig. 3; Supplement 1). These represent ecosystem services that are impacted by either widely distributed pressures or by several pressures in combination, reflecting cumulative impacts. Other ecosystem services were primarily affected by fewer activities or to a lesser spatial extent (e.g. 'Chemical resources', 'Ornamental resources', and 'Energy provision').

Overall, the ecosystem services with strongest connection to human activities (Fig. 4, Supplement 2) were identified as 'Science and education', 'Cultural heritage' and 'Recreation' (cultural services), as well as the provision of food (provisioning service) and some regulating or supporting services ('Biogeochemical cycling', 'Biodiversity' and 'Habitat'). At the other end of the scale, human activities were assessed as being little dependent on chemical, ornamental and genetic resources (provisional services; Fig. 4). Most of the individual scores (Supplement 2) were uncontroversial among the assessors, while a few were subject to longer discussion, reflecting lower certainty, such as the impact of commercial fishing on the ecosystem service 'Raw material'. In this part, the discussion led to considering fish for industrial purposes as an important part of raw material from the sea (sensu Garpe 2008 and Bryhn et al. 2015). Marine renewable energy (wind and wave power) were not included in the ecosystem service 'Energy', since Garpe (2008) and Bryhn et al. (2015) only include energy based on biogenic material in this ecosystem service category. 


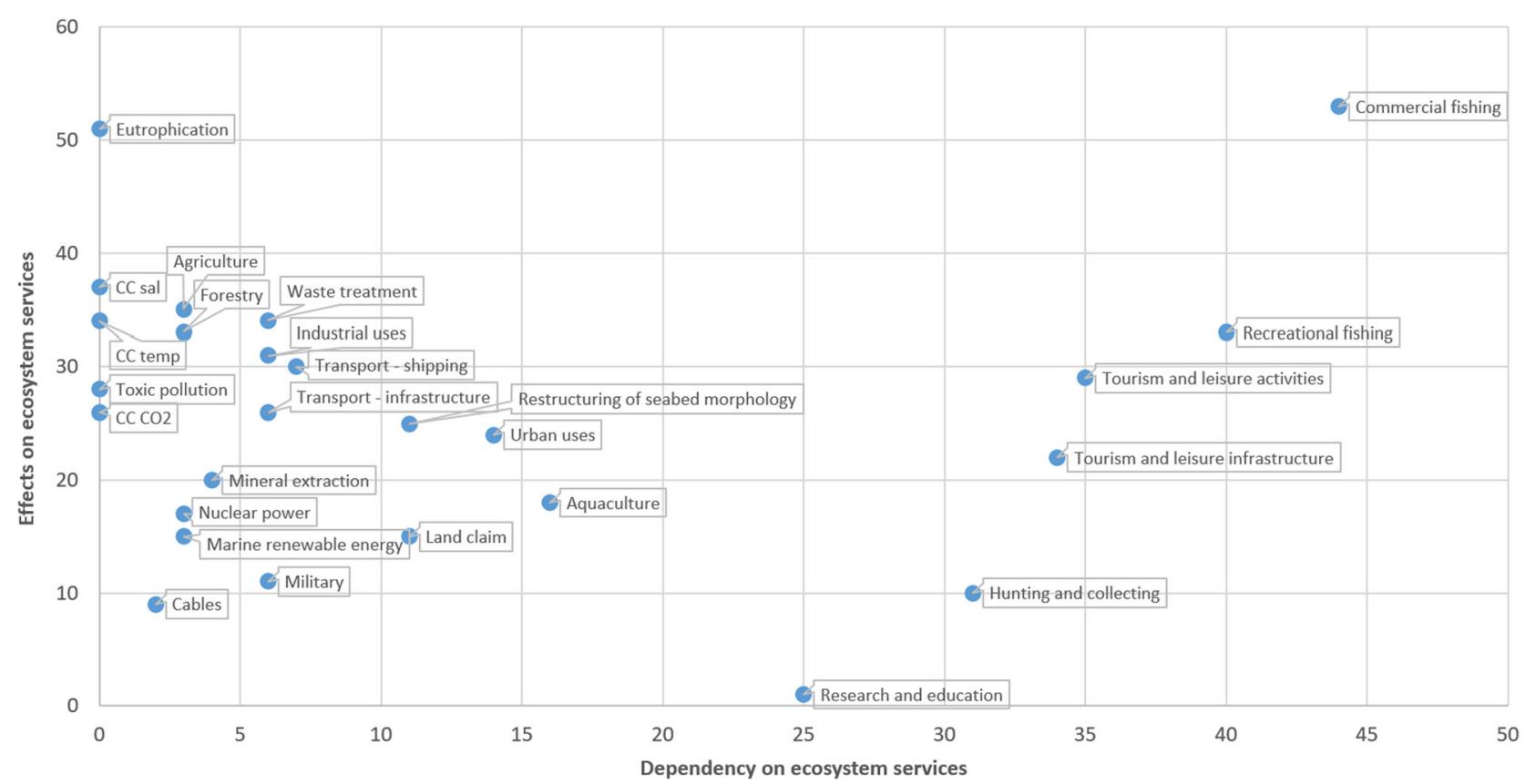

Fig. 5 Relationship between the dependencies on ecosystem services of marine human activities ( $x$-axis) and the impacts of the same human activities on ecosystem services ( $y$-axis), using the described expert evaluation method. Pressures from past emissions are not dependent on current marine ecosystem services and score 0 on the $x$-axis (highlighted in yellow)
Fig. 6 The dependency of human activities on marine ecosystem services (x-axis) and the impact of human activities on ecosystem services ( $y$-axis). The size of the bubbles represents their monetary value added. The total monetary value of all the sectors represented in the diagram is $1.5 \%$ of the Swedish gross domestic product. Note that the activity categories are more aggregated in this figure than in other figures, depending on the data availability on economic values. For data, see Appendix (Table 3)

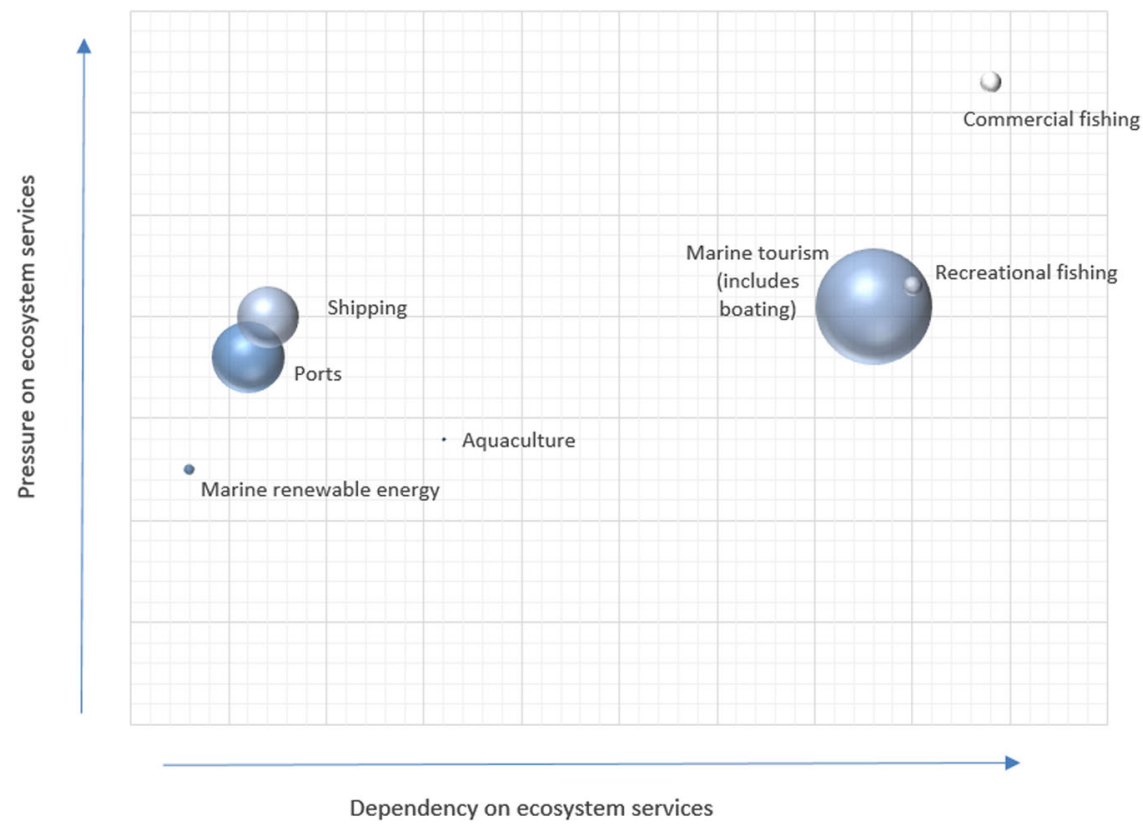

Considering individual human activities, 'commercial and recreational fish and shellfish harvesting', 'tourism and leisure activities and infrastructure', 'hunting and collecting', as well as 'scientific and educational activities' scored as being the most dependent on ecosystem services (Supplement 2). The results reflect that the extraction and harvesting of natural resources was noted as being highly dependent on various regulating or supporting and provisioning ecosystem services, and activities related to tourism additionally on cultural ecosystem services. Many human activities, including 'shipping', 'agriculture', 'forestry', 'transmission (cables)', scored very low regarding dependency on marine ecosystem services (Supplement 2).

The relative position of all studied human activities in relation to their tallied estimated dependency and impact on ecosystem services, respectively, is shown in Fig. 5. 
Figure 6, again, shows the same result when information on monetary estimates of human activities is added where available. For example, 'marine tourism' 1 and 'commercial fishing', which were both assigned as being highly dependent on ecosystem services, differed in that 'marine tourism' was identified as having lower impact on ecosystem services than 'commercial fisheries', but also a higher monetary value (indicated by the size of the bubble). Transportation related activities ('shipping' and 'ports'), which were estimated as having similar level of impact on ecosystem services as 'marine tourism', clearly differed from the latter by having a lower dependency on ecosystem services. The monetary value was also lower than for 'marine tourism' (Fig. 6).

\section{Discussion}

This study investigated and quantified the dependency and impact of human activities on ecosystem services using a structured assessment model to make use of available information for different sectors together. Comparative investigations of the impact of human activities on marine ecosystem services have been undertaken previously (e.g. World Resources Institute 2005; Giakoumi et al. 2015; Rocha et al. 2015), but have not so far integrated the analyses with an assessment of the dependency of human activities on marine ecosystem services (see, however, SWaM 2012). Ivarsson et al. (2017) developed a methodology for the latter kind of analysis, but did not proceed to testing it. Their suggested approach was considered in the development of our study, and was adapted to suit our data. Ivarsson et al. (2017) suggested a binary scoring system (0 or 1) while the present study used a 0-4 scoring system to provide a more fine-scale assessment of the impact on ecosystems services from the various activities. Using the former approach would probably yield more conspicuous results for activities with low dependencies on marine ecosystem services, such as agriculture, forestry and marine renewable energy.

According to the applied evaluation, commercial fishing and eutrophication legacies were the activities or pressures that affected marine ecosystem services most fundamentally (Fig. 5; see also Rocha et al. 2015; Barbier 2017). Commercial fishing had an exceptional position in being both highly impacting and highly dependent on ecosystem services. In all, only a few of the assessed activities were identified as having a high dependency on ecosystem

\footnotetext{
${ }^{1}$ Including all types of economic activities (e.g., restaurants, accommodation, tourist agencies) classified as tourism, within $1 \mathrm{~km}$ from the coast. This is how all European Union countries calculate the value of marine tourism, and that is the most precise method currently available.
}

services, these being mainly related to the extraction of living marine resources (fishing, hunting and collecting for commercial or recreational purposes) or tourism and recreation. Most activities had low dependencies on marine ecosystem services, including e.g. 'Urban uses', construction works, energy production and transport. These activities might be expected to take place at a similar extent regardless of the status of the marine environment, or be little influenced by a change in state, but have an effect on other human activities via their impacts on ecosystem services. Eutrophication legacies, which had among the largest impacts on ecosystem services, invoke only costs and no benefits (Fig. 5). The current loss of benefits due to eutrophication has been estimated at the scale of billions of Euros annually for the Baltic Sea region (HELCOM 2018).

In all, the results (Figs 5, 6) indicate that several human activities exert pressures on the marine environment and ecosystem services, but that only some of them would benefit substantially from a better state. The results thus suggest a lack of direct incentives for environmental adaptation for several activities. In fact, even for activities that are both dependent on and clearly affecting ecosystem services, such as commercial fisheries, incentives for voluntary environmental adaptation to favour long-term benefits have often been found inadequate (Grafton et al. 2016). However, as commercial fisheries would benefit from sustainable fish stocks and healthy habitats in the multiannual perspectives, their value should be expected to increase by improved management instruments (Squires and Garcia 2018). As marine ecosystem services are often highly valued in Swedish waters and in the Baltic Sea in general (Cole and Moksnes 2016; Oinonen et al. 2016; HELCOM 2018; Nainggolan et al. 2018), the lack of direct incentives for some sectors and actors to safeguard ecosystem services may necessitate well-designed fiscal mechanisms to enable environmental actions (Nainggolan et al. 2018). For wide-ranging activities and impacts, such as in the cases of eutrophication legacies, contamination legacies (toxic pollution), climate change and offshore commercial fishing, internationally coordinated actions are crucial also for the national management level (Nainggolan et al. 2018). The national scale was applied in the current assessment as it was considered the most useful one to support current environmental policy requirements (EC 2008, 2017). Although the assessment hence provides an overarching view, it should be recognized that there is substantial spatial variability at a more detailed scale, which the current approach does not aim to depict. For instance, ecosystem services related to marine recreation are expected to be largely confined to coastal areas, whereas commercial fishing yields higher market values in the open sea than in coastal areas of Sweden. Regarding differences among geographical areas, coastal recreation is more prominent in 
the densely populated southern parts of Sweden, for instance in the Bohuslän and Stockholm archipelagos (Jaccopucci and Gunvaldsson 2013), than in the north. For analyses to provide such differentiation, additional spatially explicit evaluations are required.

Considering the economic value of the activities (Fig. 6), it can be seen that marine tourism had a much higher monetary value nationally than fisheries. As tourism was also assessed as having a clearly lower impact on ecosystem services, a possible implication could be that marine tourism is looked upon as having higher priority than commercial fishing, for both economic and environmental reasons. However, such prioritization must also be put in the context of other societal needs, including food security (Pihlajamäki et al. 2016). The high ranking of marine tourism regarding dependency on ecosystem services, is however, well supported by literature. Naturalness is often ranked highly in importance among marine tourists (Ryan and Page 2011; Jacobsen and Tømmervik 2016), reflecting that well-functioning ecosystems are appreciated (Jacobsen and Tømmervik 2016). For instance, healthy habitats may be a key reason for visiting a certain area (Ryan and Page 2011) while high prevalence of marine litter, harmful algal blooms and other outbreaks or invasions, conversely, may deter visitors (Krelling et al. 2017; Groeneveld et al. 2018).

The DAPSIR framework used in this study to define the evaluation context was primarily useful to structure the setting of scores to address impacts from human activities on ecosystem services (and vice versa), and to ensure that the steps of the assessment were presented in an easily understandable and transparent way, supporting communication and discussion of results. Hence, this study provides an example of how the interrelationships between activities and ecosystem services can be assessed to guide management priorities and facilitate communication among stakeholder groups in support of an ecosystem-based approach. Including assessment uncertainties would be a desirable further development of the study (see e.g. Trochta et al. 2018), as would engaging a broader panel of experts to perform the assessments. These shortcomings underscore the importance for managers to interpret our results with care.

As an alternative to consensus assessment, as was the applied procedure here, it may be possible in future work to include information on differences in assessed scores between different experts, since not having to reach consensus would require less time and effort from each assessor. However, the consensus process also led to a more well-informed and balanced assessment in our view, as existing studies and results were available to the same level to all assessors. Having experts contributing with an individual set of scores each would have changed the results at some points, but as there was not much disagreement about the scores among the authors, so this alternative method would only have generated minor differences compared with the current assessment. Comparing results for different ecological settings would also be valuable, such as extending the assessment to other sea areas than the Swedish marine waters. For example, in economies with a higher dependency on the fisheries sector (in Sweden, fisheries and aquaculture account for $<0.1 \%$ of the gross domestic product; OECD 2014) could be expected to yield considerably differing results.

Importantly, the assessment model developed and used here provides a tool for communication among and within different groups of researchers, managers and stakeholders, and illumination of potential tradeoffs between different human activities and marine ecosystem services. Stakeholder involvement is increasingly advocated as a key for successful implementation of ecosystem-based management (Bryhn et al. 2017; Schreiber and Linke 2018). Ecosystem services may be difficult to understand and communicate (Beaumont et al. 2007) and the present approach may serve as one example of how to make the role of ecosystem services more easily understood, more widely discussed and analysed. This could lead to a more holistic and multidisciplinary management, highlighting both ecosystem and societal aspects of the marine environment.

Acknowledgements The Swedish Agency of Water and Marine Management financed the development of the analytical methods. We are grateful to two anonymous peer-reviewers who commented on earlier versions of the manuscript. Open access funding provided by Swedish University of Agricultural Sciences.

\section{Compliance with Ethical Standards}

Conflict of Interest The authors declare that they have no conflict of interest.

Publisher's note Springer Nature remains neutral with regard to jurisdictional claims in published maps and institutional affiliations.

Open Access This article is licensed under a Creative Commons Attribution 4.0 International License, which permits use, sharing, adaptation, distribution and reproduction in any medium or format, as long as you give appropriate credit to the original author(s) and the source, provide a link to the Creative Commons license, and indicate if changes were made. The images or other third party material in this article are included in the article's Creative Commons license, unless indicated otherwise in a credit line to the material. If material is not included in the article's Creative Commons license and your intended use is not permitted by statutory regulation or exceeds the permitted use, you will need to obtain permission directly from the copyright holder. To view a copy of this license, visit http://creativecommons. org/licenses/by/4.0/. 


\section{Appendix}

Table 3 Value added from 7 different categories of human activities and their assessed impacts and dependency on marine ecosystem services

\begin{tabular}{llll}
\hline & $\begin{array}{l}\text { Impacts on } \\
\text { ecosystem services }\end{array}$ & $\begin{array}{l}\text { Dependency on } \\
\text { ecosystem services }\end{array}$ & $\begin{array}{l}\text { Value added (Swedish } \\
\text { crowns, SEK, in thousands) }\end{array}$ \\
\hline Commercial fisheries & 53.0 & 44.0 & 650,000 \\
Ports & 26.0 & 6.0 & $7,447,000$ \\
Aquaculture & 18.0 & 16.0 & 16,588 \\
Marine renewable energy & 15.0 & 3.0 & 140,910 \\
Shipping & 30.0 & 7.0 & $5,365,000$ \\
Marine tourism & 31 & 38 & $19,235,891$ \\
Recreational fishing & 33.0 & 40.0 & 515,376 \\
\hline
\end{tabular}

Value added taken from SwAM (2017), except for recreational fisheries that is based on unpublished SwAM data. Impacts and dependency on ecosystem services were assessed in the study

${ }^{a}$ Recreational fishing excluded

\section{References}

Airoldi L, Beck MW (2007) Loss, status and trends for coastal marine habitats of Europe. Oceanogr Mar Biol 45:345-405

Anderson EP, Marengo J, Villalba R, Halloy S, Young B, Cordero D, Gast F, Jaimes E, Ruiz D (2016) Consequences of climate change for ecosystems and ecosystem services in the Tropical Andes. In: Herzog SK, Martinez R, Jørgensen PM, Tiessen H (Eds) Climate change and biodiversity in the tropical andes. Inter-American Institute for Global Change Research (IAI) and Scientific Committee on Problems of the Environment (SCOPE), São José dos Campos, p 1-18

Schreiber MA, Linke S (2018) The social dimensions of ecosystembased fisheries management. Swedish Institute for Marine Environment, Gothenburg

Arkema KK, Verutes GM, Wood SA, Clarke-Samuels C, Rosado S, Canto M, Rosenthal A, Ruckelshaus M, Guannel G, Toft J, Faries J, Silver JM, Griffin R, Guerry AD (2015) Embedding ecosystem services in coastal planning leads to better outcomes for people and nature. PNAS 112:7390-7395

Atkins JP, Burdon D, Elliott M, Gregory AJ (2011) Management of the marine environment: Integrating ecosystem services and societal benefits with the DPSIR framework in a systems approach. Mar Pollut Bull 62:215-226

BACC II author team (2015) Second assessment of climate change for the Baltic Sea Basin. Springer, Berlin

Balmford A, Bruner A, Cooper P, Costanza R, Farber S, Green RE, Jenkins M, Jefferiss P, Jessamy V, Madden J, Munro K, Myers N, Naeem S, Paavola J, Rayment M, Rosendo S, Roughgarden J, Trumper K, Turner RK (2002) Economic reasons for conserving wild nature. Science 297:950-953

Barbier EB (2017) The economics of aquatic ecosystems: an introduction to the special issue. Water Econ Policy 3:1702002

Beaumont NJ, Austen MC, Atkins JP, Burdon D, Degraer S, Dentinho TP, Derous S, Holm P, Horton T, van Ierland E, Marboe AH, Starkey DJ, Townsend M, Zarzycki T (2007) Identification, definition and quantification of goods and services provided by marine biodiversity: Implications for the ecosystem approach. Mar Pollut Bull 54:253-265

Bennett EM, Cramer W, Begossi A, Cundill G, Díaz S, Egoh BN, Geijzendorffer IR, Krug CB, Lavorel S, Lazos E, Lebel L,
Martin-Lopez B, Meyfroidt P, Mooney HA, Nel JL, Pascual U, Payet K, Pérez Harguindeguy N, Peterson GD, Prieur-Richard AH, Reyers B, Roebeling P, Seppelt R, Solan M, Tschakert P, Tscharntke T, Turner II BL, Verburg PH, Viglizzo EF, White PCL, Woodward G (2015) Linking biodiversity, ecosystem services, and human well-being: three challenges for designing research for sustainability. Curr Opin Environ Sustainability 14:76-85

Bergmann M, Gutow L, Klages M (Eds) (2015) Marine anthropogenic litter. Springer, Berlin

Böhnke-Henrichs A, Baulcomb C, Koss R, Hussain SS, de Groot RS (2013) Typology and indicators of ecosystem services for marine spatial planning and management. J Environ Manag 130:135-45

Boumans R, Roman J, Altman I, Kaufman L (2015) The Multiscale Integrated Model of Ecosystem Services (MIMES): Simulating the interactions of coupled human and natural systems. Ecosyst Serv 12:30-41

Bryhn A, Lindegarth M, Bergström L, Bergström U (2015) Ekosystemtjänster från svenska hav. Status och påverkansfaktorer (Ecosystem services from Swedish seas. Status and determinants). Havs och vattenmyndighetens rapport 2015:12. Havs- och vattenmyndigheten, Göteborg, (in Swedish with English abstract)

Bryhn AC, Lundström K, Johansson A, Ragnarsson Stabo H, Svedäng $\mathrm{H}$ (2017) A continuous involvement of stakeholders promotes the ecosystem approach to fisheries in the 8-fjord area on the Swedish west coast. ICES J Mar Sci 74:431-442

Carlsson P, Crosse JD, Halsall C, Evenset A, Heimstad ES, Harju M (2016) Perfluoroalkylated substances (PFASs) and legacy persistent organic pollutants (POPs) in halibut and shrimp from coastal areas in the far north of Norway: Small survey of important dietary foodstuffs for coastal communities. Mar Pollut Bull 105:81-87

Ceballos G, Ehrlich PR, Barnosky AD, García A, Pringle RM, Palmer TM (2015) Accelerated modern human-induced species losses: Entering the sixth mass extinction. Sci Adv 1:e1400253

Cole SG, Moksnes P-O (2016) Valuing multiple eelgrass ecosystem services in Sweden: fish production and uptake of carbon and nitrogen. Front Mar Sci 2:121

Costanza R, d'Arge R, de Groot R, Farber S, Grasso M, Hannon B, Limburg K, Naeem S, O'Neill RV, Paruelo JM, Raskin RG, Sutton P, van den Belt M (1997) The value of the world's ecosystem services and natural capital. Nature 387:253-260 
Costanza R, de Groot R, Sutton P, van der Ploeg S, Anderson SJ, Kubiszewski I, Farber S, Turner RK (2014) Changes in the global value of ecosystem services. Glob Environ Change 26:152-158

Culhane FE, Frid CLJ, Royo-Gelabert E, White L, Robinson LA (2018) Linking marine ecosystems with the services they supply: What are the relevant service providing units? Ecol Appl 28:1740-1751

EC (2008) Directive 2008/56/EC of the european parliament and of the council of 17 June 2008 establishing a framework for community action in the field of marine environmental policy (Marine Strategy Framework Directive). Off J Eur Union 164:19-40

EC (2017) Commission Decision (EU) 2017/848 of 17 May 2017 laying down criteria and methodological standards on good environmental status of marine waters and specifications and standardised methods for monitoring and assessment, and repealing Decision 2010/477/EU (Text with EEA relevance). C/ 2017/2901 Off J Eur Union L 125:43-74

Elliott M, Burdon D, Atkins JP, Borja A, Cormier R, de Jonge VN, Turner RK (2017) “And DPSIR begat DAPSI(W)R(M)!"-A unifying framework for marine environmental management. Mar Pollut Bull 118:27-40

Elliott M, Boyes SJ, Bernard S, Borja A (2018) Using best expert judgement to harmonise marine environmental status assessment and marine spatial planning. Mar Pollut Bull 133:367-377

de Groot RS, Alkemade R, Braat L, Hein L, Willemen L (2010) Challenges in integrating the concept of ecosystem services and values in landscape planning, management and decision making. Ecol Complex 7:260-272

de Groot RS, Brander L, van der Ploeg S, Costanza R, Bernard F, Braat L, Christie M, Crossman N, Ghermandi A, Hein L, Hussain S, Kumar P, McVittie A, Portela R, Rodriguez LC, ten Brink P, van Beukering P (2012) Global estimates of the value of ecosystems and their services in monetary units. Ecosyst Serv 1:50-61

Garpe K (2008) Ecosystem services provided by the Baltic Sea and Skagerrak. Report 5873. Swedish Environmental Protection Agency, Stockholm

Giakoumi S, Halpern BS, Michel LN, Gobert S, Sini M, Boudouresque C-F, Gambi M-C, Katsanevakis S, Lejeune P, Montefalcone M, Pergent G, Pergent-Martini C, Sanchez-Jerez P, Velimirov B, Vizzini S, Abadie A, Coll M, Guidetti P, Micheli F, Possingham HP (2015) Towards a framework for assessment and management of cumulative human impacts on marine food webs. Conserv Biol 29:1228-1234

Grafton RQ, Kirkley J, Kompas T, Squires D (2016) Economics for fisheries management. Routledge, London

Groeneveld RA, Bartelings H, Börger T, Bosello F, Buisman E, Delpiazzo E, Eboli F, Fernandes JA, Hamon KG, Hattam C, Loureiro M, Nunes PALD, Piwowarczyk J, Schasfoort FE, Simons SL, Walker AN (2018) Economic impacts of marine ecological change: review and recent contributions of the VECTORS project on European marine waters. Estuar, Coast Shelf Sci 201:152-163

Haight C, Larson M, Swadek RK, Kracauer Hartig E (2019) Toward a salt marsh management plan for New York City: recommendations for strategic restoration and protection. In: Perillo GME, Wolanski E, Cahoon DR, Hopkinson CS (Eds), Coastal wetlands, 2nd edn. Elsevier, Amsterdam, p 997-1022

Haines-Young R, Potschin M (2010) The links between biodiversity, ecosystem services and human well-being. In: Raffaelli DG, Frid CLJ (Eds) Ecosystem ecology: a new synthesis. Cambridge University Press, British Ecological Society, Cambridge, $p$ 110-139

Halpern BS, Walbridge S, Selkoe KA, Kappel CV, Micheli F, D'Agrosa C, Bruno JF, Casey KS, Ebert C, Fox HE, Fujita R, Heinemann D, Lenihan HS, Madin EMP, Perry MT, Selig ER,
Spalding M, Steneck R, Watson R (2008) A global map of human impact on marine ecosystems. Science 319:948-952

Halpern BS, Frazier M, Potapenko J, Casey KS, Koenig K, Longo C, Lowndes JS, Rockwood RC, Selig ER, Selkoe KA, Walbridge S (2015) Spatial and temporal changes in cumulative human impacts on the world's ocean. Nat Commun 6:7615

Hasler B, Ahtiainen H, Hasselström L, Heiskanen A-S, Soutukorva Å, Martinsen L (2016) Marine ecosystem services in Nordic marine waters and the Baltic Sea-possibilities for valuation. TemaNord 2016:501. Nordic Council of Ministers

Hautier Y, Tilman D, Isbell F, Seabloom EW, Borer ET, Reich PB (2015) Anthropogenic environmental changes affect ecosystem stability via biodiversity. Science 348:336-340

HELCOM (2018) State of the Baltic Sea. Second HELCOM holistic assessment 2011-2016. In: Baltic Sea Environment Proceedings 155. HELCOM, Helsinki

Hunsicker ME, Kappel CV, Selkoe KA, Halpern BS, Scarborough C, Mease L, Amrhein A (2015) Characterizing driver-response relationships in marine pelagic ecosystems for improved ocean management. Ecol Appl 26:651-663

Inácio M, Schernewski G, Nazemtseva Y, Baltranaitė E, Friedland R, Benz J (2018) Ecosystem services provision today and in the past: a comparative study in two Baltic lagoons. Ecol Res 33:1255-1274

Ivarsson M, Magnussen K, Heiskanen A-S, Navrud S, Viitasalo M (2017) Ecosystem services in MSP: Ecosystem services approach as a common Nordic understanding for MSP. TemaNord 2017:536. Nordic Council of Ministers, Copenhagen

Jaccopucci A, Gunvaldsson M (2013) Skärgårdsdestinationer (Archipelago destinations). Bachelor's thesis, University of Södertörn

Klusek Z (2016) Seasonal and diel variability of the underwater noise in the Baltic Sea. J Acoustical Soc Am 139:1537

Kok MTJ, Kok K, Peterson GD, Hill R, Agard J, Carpenter SR (2017) Biodiversity and ecosystem services require IPBES to take novel approach to scenarios. Sustainability. Science 12:177-181

Krelling AP, Williams AT, Turrad A (2017) Differences in perception and reaction of tourist groups to beach marine debris that can influence a loss of tourism revenue in coastal areas. Mar Policy 85:87-99

La Notte A, D'Amato D, Mäkinen H, Paracchini ML, Liquete C, Egoh B, Geneletti D, Crossman ND (2017) Ecosystem services classification: a systems ecology perspective of the cascade framework. Ecol Indic 74:392-402

Liquete C, Piroddi C, Drakou EG, Gurney L, Katsanevakis S, Charef A, Egoh B (2013) Current status and future prospects for the assessment of marine and coastal ecosystem services: a systematic review. PLoS ONE 8:e67737

Lindegren M, Holt BG, MacKenzie BR, Rahbek C (2018) A global mismatch in the protection of multiple marine biodiversity components and ecosystem services. Sci Rep. 8:4099

Lotze HK, Lenihan HS, Bourque BJ, Bradbury RH, Cooke RG, Kay MC, Kidwell SM, Kirby MX, Peterson CH, Jackson JBC (2006) Depletion, degradation, and recovery potential of estuaries and coastal seas. Science 312:1806-1809

Mach ME, Martone RG, Chan KMA (2015) Human impacts and ecosystem services: Insufficient research for trade-off evaluation. Ecosyst Serv 16:112-120

Maes J, Teller A, Erhard M, Grizzetti B, Barredo JI, Paracchini ML, Condé S, Somma F, Orgiazzi A, Jones A, Zulian A, Vallecilo S, Petersen JE, Marquardt D, Kovacevic V, Abdul Malak D, Marin AI, Czúcz B, Mauri A, Loffler P, Bastrup-Birk A, Biala K, Christiansen T, Werner B (2018) Mapping and assessment of ecosystems and their services: an analytical framework for ecosystem condition. Publications office of the European Union, Luxembourg 
Martin DM, Piscopo AN, Chintala MM, Gleason TR, Berry W (2018) Developing qualitative ecosystem service relationships with the driver-pressure-state-impact-response framework: a case study on Cape Cod, Massachusetts. Ecol Indic 84:404-415

Mazor T, Doropoulos C, Schwarzmueller F, Gladish DW, Kumaran N, Merkel K, Di Marco M, Gagic V (2018) Global mismatch of policy and research on drivers of biodiversity loss. Nat Ecol Evolut 2:1071-1074

McBride MF, Garnett ST, Szabo JK, Burbidge AH, Butchart SHM, Christidis L, Dutson G, Ford HA, Loyn RH, Watson DM, Burgman MA (2012) Structured elicitation of expert judgments forthreatened species assessment: a case study on acontinental scale using email. Methods Ecol Evolut 3:906-920

Nainggolan D, Hasler B, Andersen HE, Gyldenkærne S, Termansen M (2018) Water quality management and climate change mitigation: cost-effectiveness of joint implementation in the Baltic Sea region. Ecol Econ 144:12-26

OECD (2014) OECD environmental performance reviews. OECD, Paris

Oinonen S, Grønbæk L, Laukkanen M, Levontin P, Lindroos M, Nieminen E, Parkkila K, Pintassilgo P, Pulkkinen H, Romakkaniemi A (2016) International fisheries management and recreational benefits: the case of Baltic salmon. Mar Resour Econ 31:433-451

OSPAR (2017) Intermediate assessment. https://oap.ospar.org/en/ospar-a ssessments/intermediate-assessment-2017/. Accessed 6 Apr 2019

Österblom H, Crona BI, Folke C, Nyström M, Troell M (2017) Marine ecosystem science on an intertwined planet. Ecosystems 20:54-61

Palumbi SR, Sandifer PA, Allan JD, Beck MW, Fautin DG, Fogarty MJ, Halpern BS, Incze LS, Leong JA, Norse E, Stachowicz JJ, Wall DH (2009) Managing for ocean biodiversity to sustain marine ecosystem services. Front Ecol Environ 7:204-211

Patrício J, Elliott M, Mazik K, Papadopoulou KN, Smith CJ (2016) DPSIR - Two decades of trying to develop a unifying framework for marine environmental management? Front Mar Sci 3:177

Pihlajamäki M, Sarkki S, Karjalainen TP (2016) Food or feed? The contribution of Baltic herring fisheries to food security and safety. In: Olsson AS, Araújo SM, Vieira MF (Eds) Food futures: ethics, science and culture. Wageningen Academic Publishers, Wageningen, p 239-243

Rocha J, Yletyinen J, Biggs R, Blenckner T, Peterson G (2015) Marine regime shifts: drivers and impacts on ecosystems services. Philos Trans R Soc B: Biol Sci 370:20130273

Ryan C, Page S (2011) Tourism management. Routledge, London \& New York, NY

Sandifer PA, Sutton-Grier AE, Ward BP (2015) Exploring connections among nature, biodiversity, ecosystem services, and human health and well-being: opportunities to enhance health and biodiversity conservation. Ecosyst Serv 12:1-15

Schernewski G, Friedland R, Carstens M, Hirt U, Leujak W, Nausch G, Neumann T, Petenati T, Sagert S, Wasmund N, von Weber M (2015) Implementation of European marine policy: New water quality targets for German Baltic waters. Mar Policy 51:305-321

Schernewski G, Inácio M, Nazemtseva Y (2018) Expert based ecosystem service assessment in coastal and marine planning and management: a Baltic lagoon case study. Front Environ Sci 6:19
Schuur EAG, McGuire AD, Schädel C, Grosse G, Harden JW, Hayes DJ, Hugelius G, Koven CD, Kuhry P, Lawrence DM, Natali SM, Olefeldt D, Romanovsky VE, Schaefer K, Turetsky MR, Treat CC, Vonk JE (2015) Climate change and the permafrost carbon feedback. Nature 520:171-179

Selim SA, Blanchard JL, Bedford J, Webb TJ (2016) Direct and indirect effects of climate and fishing on changes in coastal ecosystem services: a historical perspective from the North Sea. Regional Environ Change 16:341-351

Smith M, Wallace K, Lewis L, Wagner C (2015) A structured elicitation method to identify key direct risk factors for the management of natural resources. Heliyon 1:e00043

Squires D, Garcia S (2018) The least-cost biodiversity impact mitigation hierarchy with a focus on marine fisheries and bycatch issues. Conserv Biol 32:989-997

Statistics Sweden (2017) Aquaculture in Sweden in 2016. Statistiska meddelanden JO 60 SM 1701. Statistics Sweden, Stockholm, In Swedish

Jacobsen JKS, Tømmervik H (2016) Leisure traveller perceptions of iconic coastal and fjord countryside areas: Lush naturalness or remembrance of agricultural times past? Land Use Policy $54: 38-46$

SwAM (2012) God havsmiljö 2020 Del 1: Inledande bedömning av miljötillståndet och ekonomisk analys (Good sea environment 2020 Part 1: Initial assessment of the environmental condition and economic analysis). Swedish Agency for Marine and Aquatic Management, Göteborg, In Swedish

SwAM (2017) Ekonomisk statistik om sektorer som är beroende av havet (Economics statistics on sectors dependent on the sea). Havs- och vattenmyndighetens rapport 2017:16. Statistics Sweden, Stockholm, In Swedish

SwAM (2018a) Havsplan Bottniska Viken. Samrådshandling (Marine plan, Gulf of Bothnia. Joint advice document). Swedish Agency for Marine and Aquatic Management, Göteborg, In Swedish

SwAM (2018b) Havsplan Östersjön. Samrådshandling (Marine plan, Baltic Proper. Joint advice document). Swedish Agency for Marine and Aquatic Management, Göteborg, In Swedish

SwAM (2018c) Havsplan Västerhavet. Samrådshandling (Marine plan, Western Sea. Joint advice document). Swedish Agency for Marine and Aquatic Management, Göteborg, In Swedish

SwAM (2018d) Symphony. Integrerat planeringsstöd för statlig havsplanering utifrån en ekosystemansats (Symphony. Integrated planning support for governmental maritime planning based on an ecosystem approach). Havs- och vattenmyndighetens rapport 2018:1. Swedish Agency for Marine and Aquatic Management, Göteborg, in Swedish

Trochta JT, Pons M, Rudd MB, Krigbaum M, Tanz A, Hilborn R (2018) Ecosystem-based fisheries management: Perception on definitions, implementations, and aspirations. PLoS ONE 13: e 0190467

World Resources Institute (2005) Millennium assessment. Ecosystems and human wellbeing. A framework for assessment. Island Press, Washington, p 155

Worm B (2016) Averting a global fisheries disaster. PNAS 113:4895-4897 